UCRL-ID-131717

\title{
The Current Radiological Status of Utirik Atoll
}

\author{
William L. Robison
}

August 1998

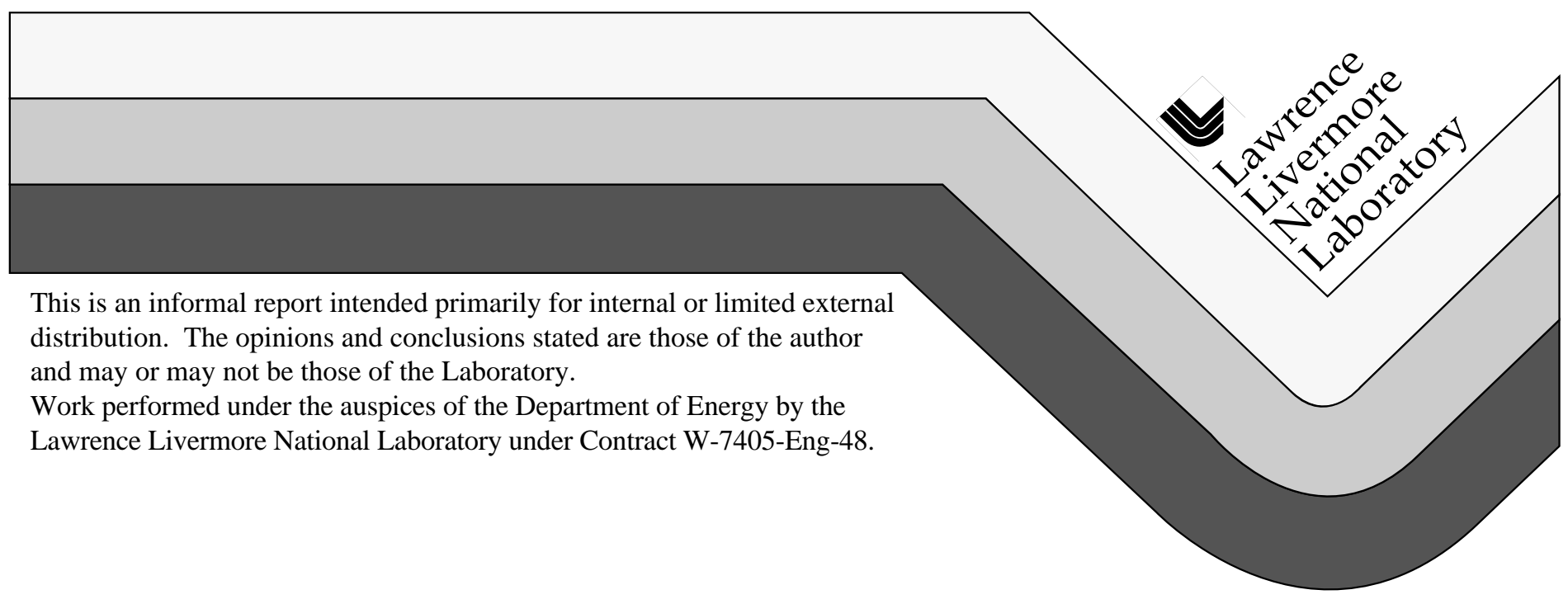




\section{DISCLAIMER}

This document was prepared as an account of work sponsored by an agency of the United States Government. Neither the United States Government nor the University of California nor any of their employees, makes any warranty, express or implied, or assumes any legal liability or responsibility for the accuracy, completeness, or usefulness of any information, apparatus, product, or process disclosed, or represents that its use would not infringe privately owned rights. Reference herein to any specific commercial product, process, or service by trade name, trademark, manufacturer, or otherwise, does not necessarily constitute or imply its endorsement, recommendation, or favoring by the United States Government or the University of California. The views and opinions of authors expressed herein do not necessarily state or reflect those of the United States Government or the University of California, and shall not be used for advertising or product endorsement purposes.

This report has been reproduced directly from the best available copy.

Available to DOE and DOE contractors from the

Office of Scientific and Technical Information

P.O. Box 62, Oak Ridge, TN 37831

Prices available from (615) 576-8401, FTS 626-8401

Available to the public from the

National Technical Information Service

U.S. Department of Commerce

5285 Port Royal Rd.

Springfield, VA 2216 


\title{
The Current Radiological Status of Utirik Atoll
}

\author{
WilliamL.Robison
}

Manuscript date: July 1998

Lawrence Livermore National Laboratory University of California • Livermore, California • 94551 


\section{Introduction}

A preliminary radiological survey was conducted at Utirik Atoll in 1978 as part of the Northern Marshall Islands Radiological Survey (NMIRS). A dose assessment based on these limited data indicated a relatively low dose of about $0.12 \mathrm{mSv}$ to people living on Utirik in 1978 (Robison et al., 1982).

A much more detailed radiological survey was conducted in April of both 1993 and 1994. Aerial photos of the islands of Utirik Atoll were taken as part of the 1978 NMIRS. The sampling grids for the 1993 and 1994 surveys are shown overlaid on these aerial photos in Figures 1, 2, 3, and 4. External gamma measurements and a collection of either drinking coconuts or copra coconuts were made at each location. Pandanus, breadfruit, lime, and banana were collected where available. Ground water was collected in 1993/94 from four wells on Utirik Island and two wells on Aon Island. Surface soil and soil profiles were collected at some of the grid points on each of the islands at the atoll in 1993/94.

A comparison of the number of samples collected in 1978 and 1993/94 are shown in Table 1. A detailed listing of the samples collected in the 1993/94 radiological survey at Utirik Atoll is given in Table 2. The number of vegetation samples collected in 1993/94 is nearly a factor of 7 greater than in 1978. Soil samples collected in 1993/94 exceeded the number collected in 1978 by more than a factor of 4 . Consequently, extensive data are now available for the islands at Utirik Atoll and form the basis for the current dose assessment for the atoll.

Table 1. Comparison of the number of samples collected in 1978 vs. 1993/94.

\begin{tabular}{|c|c|c|c|c|c|c|c|c|c|}
\hline \multirow[b]{2}{*}{$\begin{array}{l}\text { Environmental } \\
\text { sample }\end{array}$} & \multirow{2}{*}{$\begin{array}{l}\text { Utirik } \\
1978\end{array}$} & \multirow{2}{*}{$\begin{array}{l}\text { Island } \\
1993 / 94\end{array}$} & \multicolumn{2}{|c|}{ Aon Island } & \multicolumn{2}{|c|}{ Bigrak Island } & \multicolumn{2}{|c|}{ Elluk Island } & \multirow{2}{*}{$\begin{array}{c}\text { Total } \\
19781993 / 94\end{array}$} \\
\hline & & & 1978 & $1993 / 94$ & 1978 & $1993 / 94$ & 1978 & $1993 / 94$ & \\
\hline Vegetation & 38 & 293 & 18 & 125 & 14 & 45 & - & 11 & 474 \\
\hline Soil (profiles) ${ }^{\mathrm{a}}$ & $165(28)$ & $866(148)$ & $58(10)$ & 196(34) & $54(8)$ & 108(19) & - & $10(2)$ & $277(46) 1180(203)$ \\
\hline $\begin{array}{l}\text { Groundwater } \\
\text { Marine }\end{array}$ & 1 & 4 & - & 2 & - & - & - & - & \\
\hline Animal & 2 & 1 & - & - & - & - & - & - & \\
\hline Fowl & 1 & 1 & - & - & - & - & - & - & \\
\hline
\end{tabular}

a The numbers in parentheses are the number of complete soil profiles. 
Table 2. The samples collected in the 1993/94 radiological survey at Utirik Atoll.

\begin{tabular}{|c|c|c|c|c|}
\hline \multicolumn{5}{|c|}{ Samples from the 1993/94 field missions to Utirik Atoll } \\
\hline \multirow{2}{*}{$\begin{array}{l}\text { Environmental sample } \\
\text { ormeasurement }\end{array}$} & \multicolumn{4}{|c|}{ Number of samples } \\
\hline & Utirik Island & Aon Island & Bigrak Island & Eluk Island \\
\hline \multicolumn{5}{|l|}{ Terrestrial foods } \\
\hline Drinking coconut meat & 122 & 59 & 17 & 4 \\
\hline Drinkingcoconutjuice & 122 & 58 & 17 & 4 \\
\hline Copracoconuts & 23 & 2 & 3 & 1 \\
\hline Pandanus & 17 & 4 & 5 & 2 \\
\hline Breadfruit & 6 & 5 & - & - \\
\hline Papaya & 1 & - & - & - \\
\hline Banana & 1 & - & - & - \\
\hline Edible husks & 1 & - & - & - \\
\hline Groundwater & $4^{*}$ & 2 & - & - \\
\hline Animal & 1 & - & - & - \\
\hline Fowl & 1 & - & - & - \\
\hline External Gamma & 11 & 84 & 40 & - \\
\hline Soil & 866 & 196 & 108 & 10 \\
\hline Soil profiles & 148 & 34 & 19 & 2 \\
\hline
\end{tabular}

\section{Basis of the Dose Assessment}

The most significant bomb-related radionuclides remaining in soil and the surrounding environment of Utirik Atoll are ${ }^{137} \mathrm{Cs},{ }^{90} \mathrm{Sr},{ }^{239+240} \mathrm{Pu}$, and ${ }^{241} \mathrm{Am}$. The coral soils of Utirik Atoll contain only about a factor of 3 greater than the amount of residual radioactivity that might be expected from global fallout alone. However, the unique chemical composition of coral soil-primarily Ca-Mg-Sr carbonate with little or no clay and low potassium content- make ${ }^{137} \mathrm{Cs}$ more available for plant uptake. Therefore, we have collected and analyzed a variety of locally available terrestrial food products (coconut, breadfruit, papaya, Pandanus, etc.) along with associated studies on the soil, water, air, and other local foods. Our assessment includes all potential routes by which radiation exposure could occur through five critical pathways.

\section{Pathway}

Terrestrial foods

The dose from intake of terrestrial foods was calculated using the data from the 1978 and 1993/94 surveys.

Marine foods

The data from marine samples collected in 1978 were used to calculate the dose from consumption 
of marine foods. The 1978 results were decay corrected to 1998.

Groundwater

External gamma exposure

Inhalation
The 1993/94 data were used to calculate the dose from the ingestion of ground water.

The data collected in 1993/94 were used to calculate the external gamma dose of each of the islands.

The dose from inhalation of resuspended soil was calculated using the concentration $239+240 \mathrm{Pu}$ and ${ }^{241} \mathrm{Am}$ in the surface soil on Utirik Island and our soil-resuspension model developed from experiments at Enewetak, Bikini, and Rongelap Atolls.

\section{Diet}

The diet model we use to calculate the dose for residence on Utirik Atoll assumes that about one half of the diet consists of locally grown foods (drinking coconut, copra, breadfruit, Pandanus, fish, clams, turtles and other terrestrial and marine foods), and that the other half of the diet consists of imported foods (rice, flour, sugar, meats, fish, soda, and other items). Details of this diet have appeared in our other publications, and will be in the detailed dose assessment report for Utirik Island that we will soon publish.

This diet model has predicted very well the ${ }^{137} \mathrm{Cs}$ concentrations observed over the last several year in the body of the Utirik and Rongelap communities by the Brookhaven National Laboratory (BNL) ${ }^{137}$ Cs Wholebody Counting program (Robison and Sun, 1997).

\section{Scientific Peer Review of our Program}

Our environmental program has had nine independent scientific reviews in the past 18 years. These independent scientific reviews have included some of the best scientists in the world that understand radionuclide cycling and transport, radiobiology, dose assessment, analytical methods and quality control procedures. The last two reviews were in 1993/94 and in 1995/96. The 1993/94 review was made by a 15 member panel of top scientists convened by the United States National Academy of Sciences. The 1995/96 review was made by a 12 member panel of top international scientist coordinated and hosted by the International Atomic Energy Agency (IAEA) in Vienna, Austria. 
All of the review groups have validated our data and dose assessment methods, and said they are of excellent quality. The U.S. National Academy of Sciences said our data are correct (NRC, 1994). The IAEA panel of international scientists said our data were correct and extensive, and no further corroboration is required (IAEA, 1998). They also agreed that our dose assessment methods were based on most current knowledge, and are correct based on the assumptions used for the diet.

In summary, we have conducted our program all of these years with extensive peer review, and our program has received strong support from both national and international scientists. These extensive reviews provide assurance to you that our data are correct, and you can use our reports to help make your decisions.

\section{Results of the Dose Assessment}

To provide a reference point for discussing the dose from bomb-related radionuclides for living on Utirik Atoll today, we will look at the background dose in the Marshall Islands and other world-wide locations. The background dose is the dose resulting from naturally occurring radiation in our environment. Since people have lived on earth, we have lived with a "background" of radiation that is part of the natural world. This "background dose" has several sources, and has been measured in thousands of locations around the world.

The sources of the background dose in the Marshall Islands is shown in Table 3. Note the significant contribution from the naturally occurring ${ }^{210} \mathrm{Po}$ and ${ }^{210} \mathrm{~Pb}$ isotopes that occurs from eating fresh fish. The background effective dose in the Marshall Islands presented is less than that we have shown during other meetings this past year. This change is due to revised dose conversion factors and gut transfer factors for naturally occurring ${ }^{210} \mathrm{Po}$ and ${ }^{210} \mathrm{~Pb}$ from the International Commission on Radiological Protection [ICRP] (ICRP, 1996). Consequently, the effective dose received from eating fresh fish is less than previously thought based on the latest ICRP data and is reflected in figures 5, 6, and 7. The Marshall Island average background dose of about $1.5 \mathrm{mSv}$ is compared with the average background dose for the United States, Europe, and other locations in Figure 5. The average background dose in the Marshall Islands is less than in the United States and Europe and significantly less than other locations around the world (India, South America, Italy, China, etc.) where many people live (UNSCEAR, 1993).

The maximum annual effective dose we estimate for living on Utirik in 1998 is $0.037 \mathrm{mSv}$. About $75 \%$ of this dose comes from ${ }^{137} \mathrm{Cs}$ in foods grown locally on the island, and another $20 \%$ to $25 \%$ from external gamma exposure also originating from ${ }^{137} \mathrm{Cs}$. Consequently, about $99 \%$ of the estimated maximum annual dose is due to ${ }^{137} \mathrm{Cs}$. The ${ }^{137} \mathrm{Cs}$ disappears from your atoll because of radiological decay; it disappears with a half life of 30.1 years. This means that in 30 years from 1998 (year 2028) there will be one half as much ${ }^{137} \mathrm{Cs}$ as there is in 1998.

The average maximum effective dose of $0.037 \mathrm{mSv}$ is shown relative to the average effective background dose in the Marshall Islands, United States, Europe, and other locations in Figure 5. The dose from bomb-related radionuclides presently 
Table 3. Marshall Island background dose

\begin{tabular}{lc}
\hline Source & $\begin{array}{c}\text { Effective Dose Rate } \\
\mathrm{mSv} \mathrm{y}^{-1}\end{array}$ \\
\hline Cosmic & 0.22 \\
Comogenic & 0.01 \\
Terrestrial & 0.01 \\
$40 \mathrm{~K}$ & 0.18 \\
210Po (diet primarily fresh fish) & 0.96 \\
210Pb (diet pirmarily fresh fish) & 0.06 \\
& 1.5 \\
\hline
\end{tabular}

on Utirik Atoll is very small, and is only 1.2 to $2.3 \%$ of the U.S. and Marshall Islands background dose, respectively.

The total effective dose that a person living on Utirik receives is the sum of the background dose, plus the man-made, bomb-related dose. This combined, total effective dose is shown in Figure 6, relative to the U.S. and European background doses. The average total effective dose to a person living on Utirik Atoll today is less than the average background effective dose received throughout Europe and the United States. In other words, people living on Utirik Atoll receive less total dose from radiation on average than other people in the world, and much less than some areas of the world.

As we mentioned earlier, ${ }^{137} \mathrm{Cs}$ is constantly disappearing because of radiological decay. Consequently, the dose from ${ }^{137} \mathrm{Cs}$ on Utirik Atoll gets less every year. So in Figure 7, we show a comparison of the bomb-related dose summed over 50 years compared with the background doses for the Marshall Islands, United States, and Europe summed over $50 \mathrm{y}$. This shows that the dose of $1.2 \mathrm{mSv}$ over $50 \mathrm{y}$ is only 0.8 to $1.5 \%$ of the integrated 50-y background dose in the U.S. and Marshall Islands, respectively.

The dose summed over 50 years is calculated assuming that only radiological decay proides a loss of ${ }^{137} \mathrm{Cs}$ from the atoll. However, some ${ }^{137} \mathrm{Cs}$ is found in the well water. Some of the ${ }^{137} \mathrm{Cs}$ in the soil gets to the well water during periods of heavy rainfall. Once in the well water, it is no longer available for uptake into foods (coconut, breadfruit, etc.), and it eventually is distributed into the oceans of the world. Consequently, this environmental process is helping remove ${ }^{137} \mathrm{Cs}$ from the atoll in addition to radiological decay.

We are currently studying the amount of this loss of ${ }^{137} \mathrm{Cs}$ over a period of time. Although we don't know the exact rate of loss of ${ }^{137} \mathrm{Cs}$ by this rainfall-leaching 
environmental process, we do know that the summed dose over 50 years for the man-made radionuclides will be considerably less than that shown in Figure 7.

\section{RiskAssessment}

The cancer risk from bomb-related radiation for residence on Utirik Atoll beginning in 1998 is calculated using a 70 year accumulated dose, a population of 500 people, and the radiation cancer risk factors from the latest Biological Effects of Ionizing Radiation report (NCR, 1990).

The expected number of cancer cases from a 70 year integral dose from bombrelated radiation at Utirik Island for 500 residents is 0.04 cases. In other words, essentially no cancer cases are expected because of bomb-related doses received by people living on Utirik today. Even with all the uncertainties considered, the likelihood is quite high $(\sim 96 \%)$ that there will be zero cancer cases over the next 70 years due to bomb-related radiation dose at Utirik Atoll.

\section{Summary}

The dose received from bomb-related radiation living on Utirik Atoll today is very, very low. The total dose to Utirik residents (that is, bomb-related dose plus background dose) is less than most people throughout the world receive, and much less than many others. Consequently, people can live on Utirik today without concern about radiological exposure and enjoy life on their beautiful atoll.

\section{References}

International Atomi Energy Agency, I.A.E.A. (1998), Radiological Conditions at Bikini Atoll: Prospects for Resettlement, International Atomic Energy Agency, Vienna, Austria, Radiological Assessment Reports Series.

International Commission on Radiological Protection, I.C.R.P. (1996), Agedependent Doses to Members of the Public from Intake of Radionuclides: Part 5 Compilation of Ingestion and Inhalation Dose Coefficients, ICRP Publication 72, Pergamon Press.

National Research Council, N.R.C. (1990), Health Effects of Exposure to Low Levels of Ionizing Radiation, National Academy Press, Washington, DC.

National Research Council, N.R.C. (1994), Radiological Assessment for Resettlement of Rongelap in the Republic of the Marshall Islands, Committee on Radiological Safety in the Marshall Islands, National Academy Press, Washington, DC. 
Robison, W.L. and Sun, C. (1997), The Use of Comparative ${ }^{137 C}$ s Body Burden Estimates from Environmental Data/Models and Whole Body Counting to Evaluate Diet Models for the Ingestion Pathway," Health Physics 73(1), 152-166.

Robison, W.L., Mount, M.E, Phillips, W.A., Conrado, C.L, Stuart, M.L., and Stoker, A.C. (1982), The Northern Marshall Islands Radiological Survey: Terrestrial Food Chain and Total Doses, Lawrence Livermore National Laboratory, Livermore, CA, UCRL-52853, Part 4.

United Nations Committee on the Effects of Atomic Radiation, UNSCEAR (1993), Sources, Effects, and Risks of Ionizing Radiation, 1993 report to the General Assembly with annexes, United Nations, NY. 


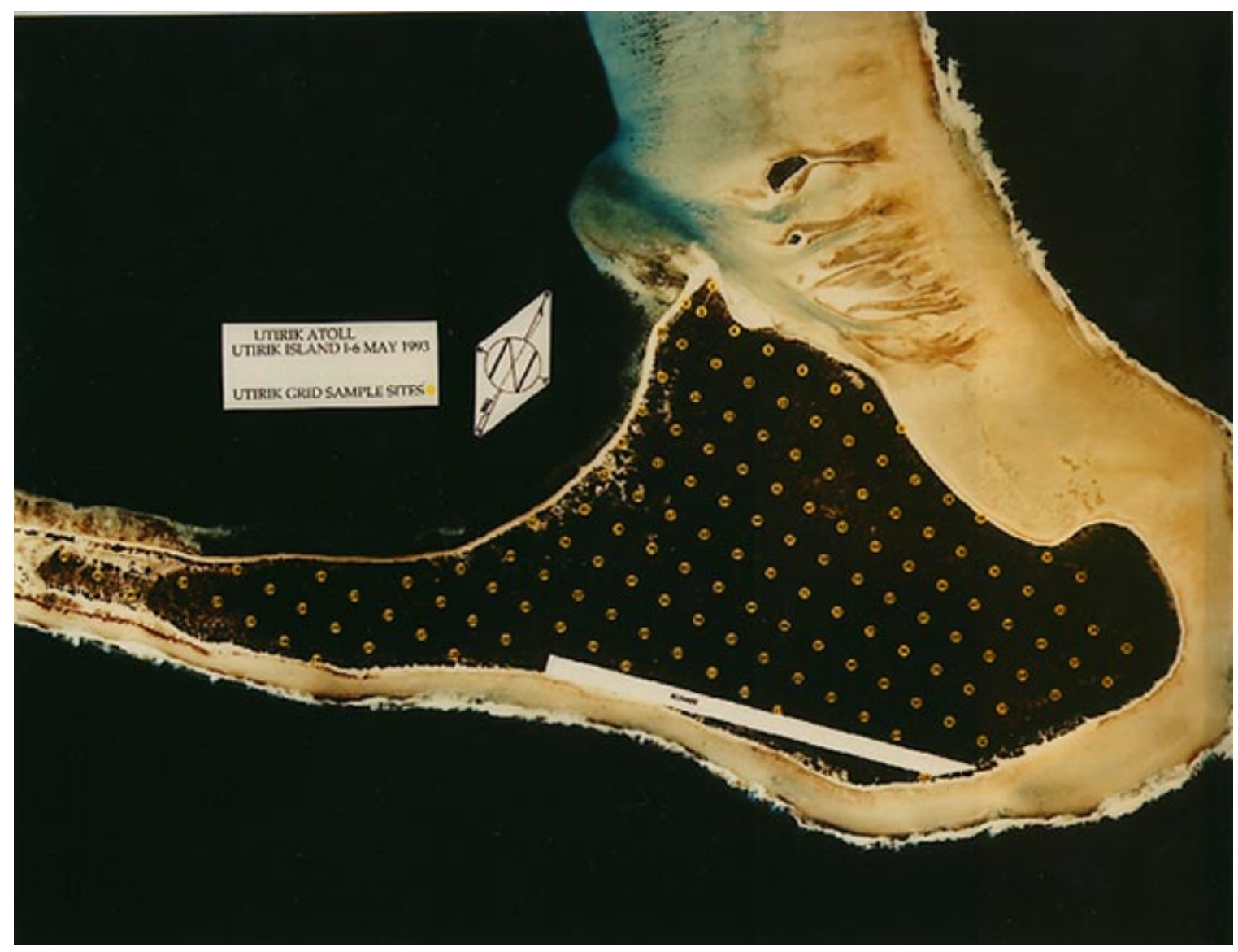

Figure 1. Utirik Island, Utirik Atoll, sample sites. 


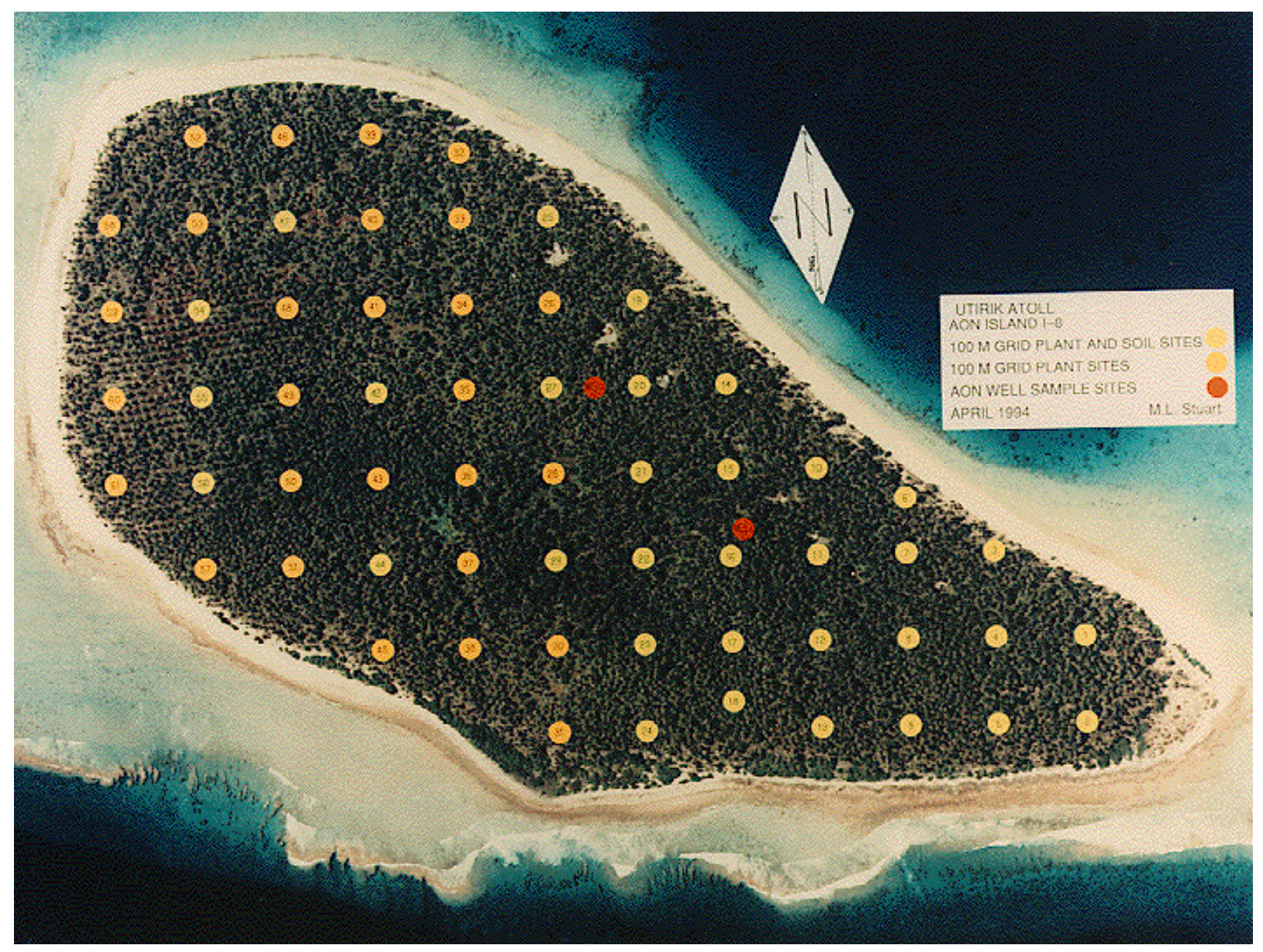

Figure 2. Aon Island, Utirik Atoll, sample sites. 


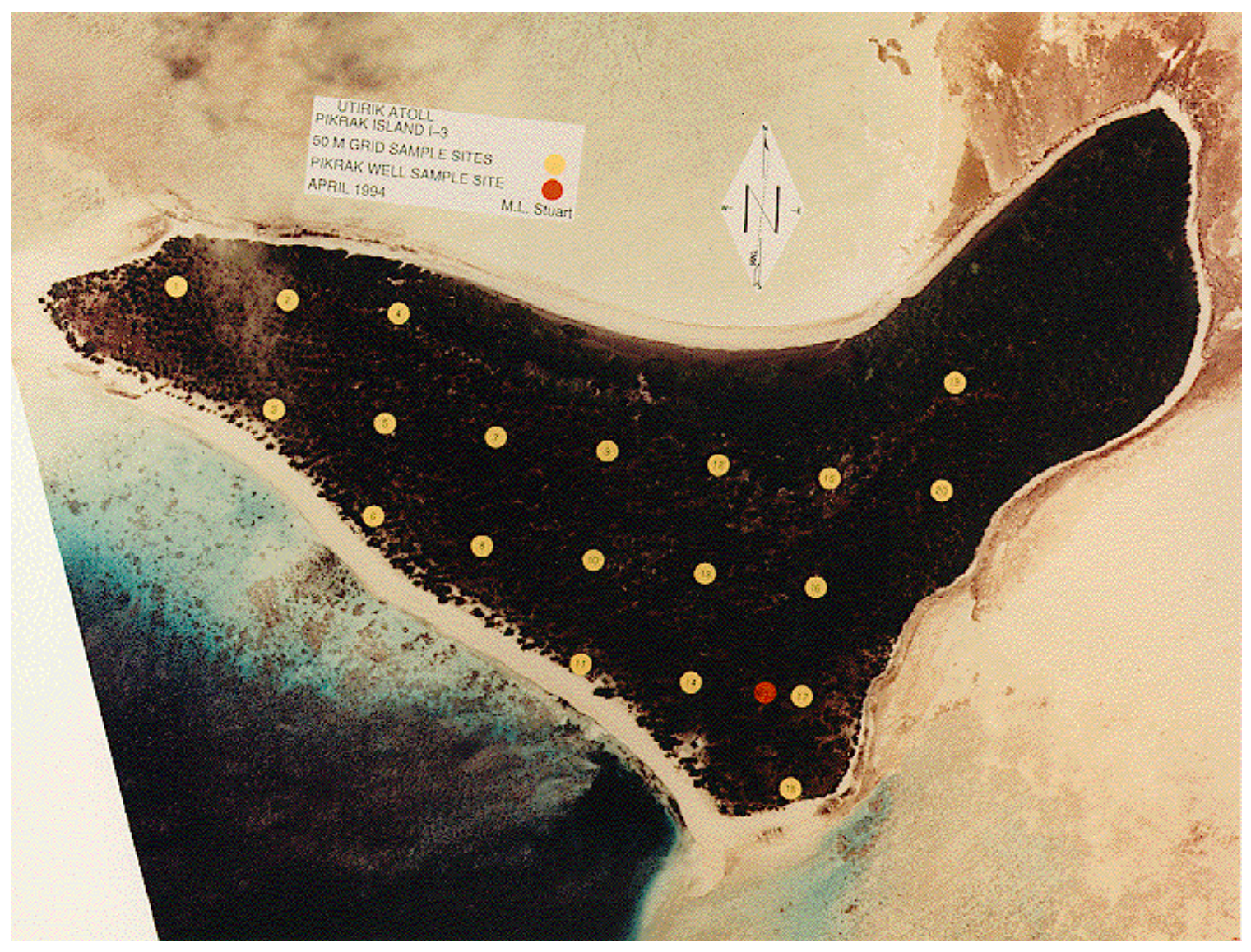

Figure 3. Bikrak Island, Utirik Atoll, sample sites. 


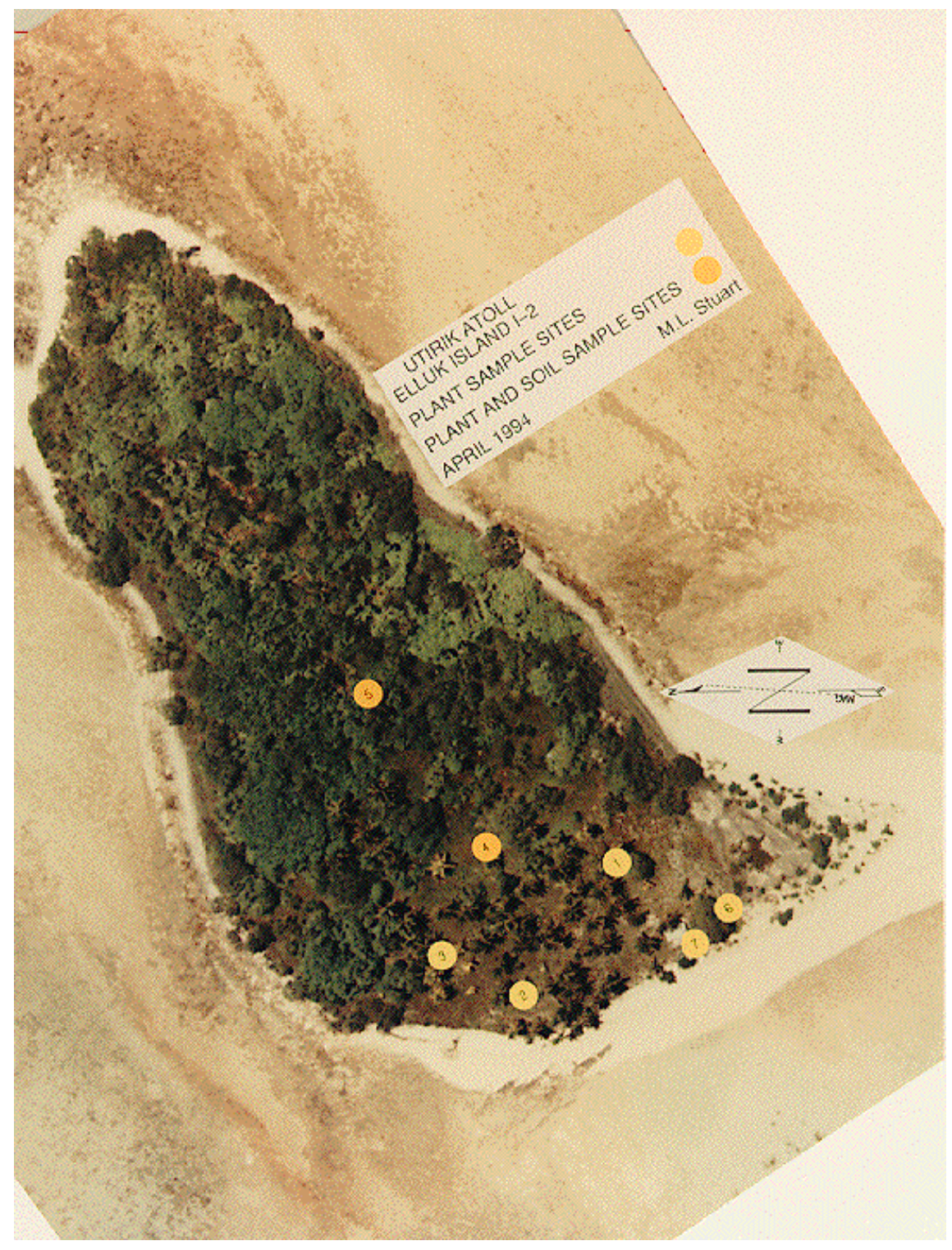

Figure 4. Eulluk Island, Utirik Atoll, sample sites. 


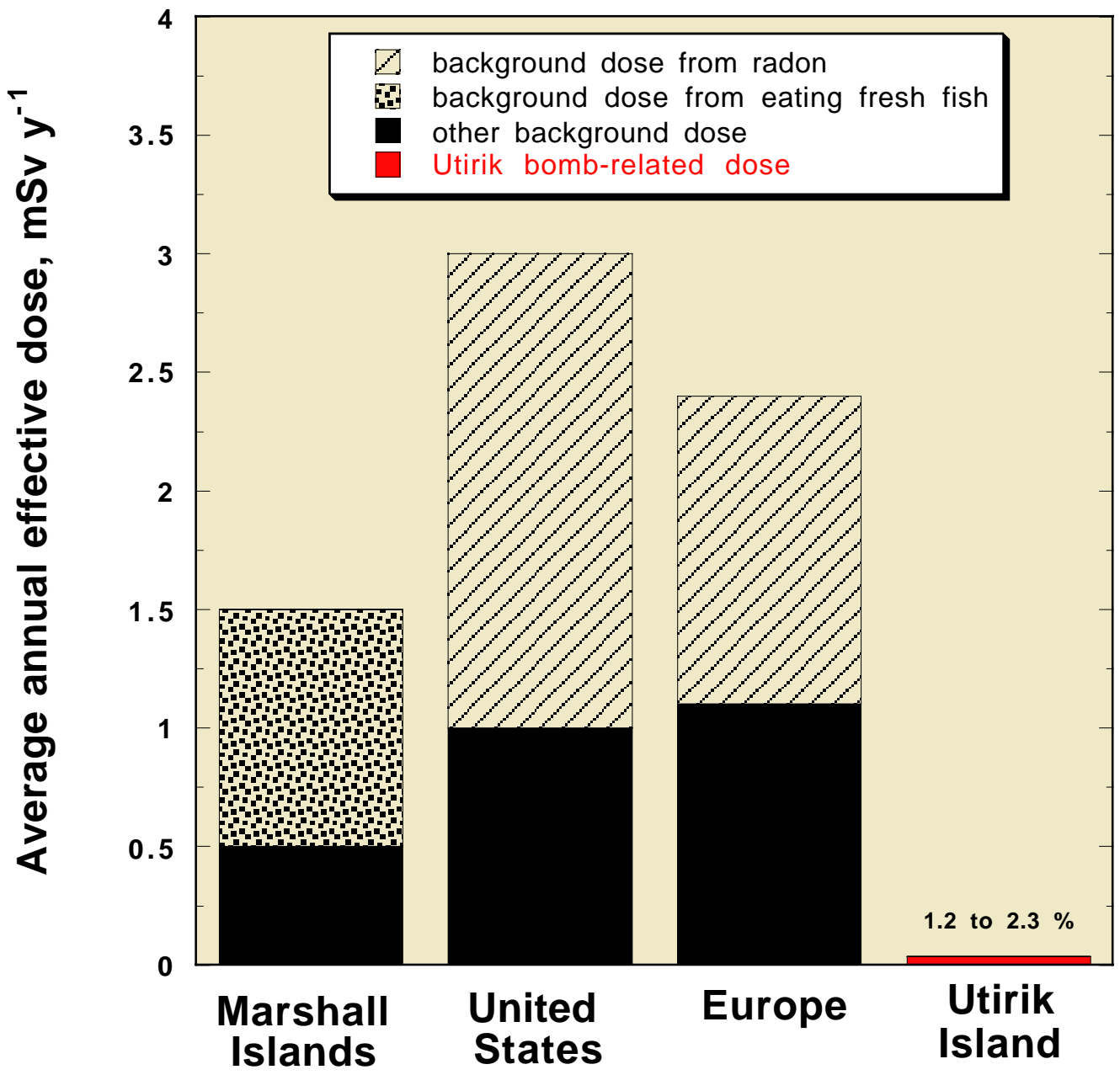

Figure 5. Utirik bomb-related average annual effective dose compared to average background doses in the Marshall Islands, United States, and Europe. 


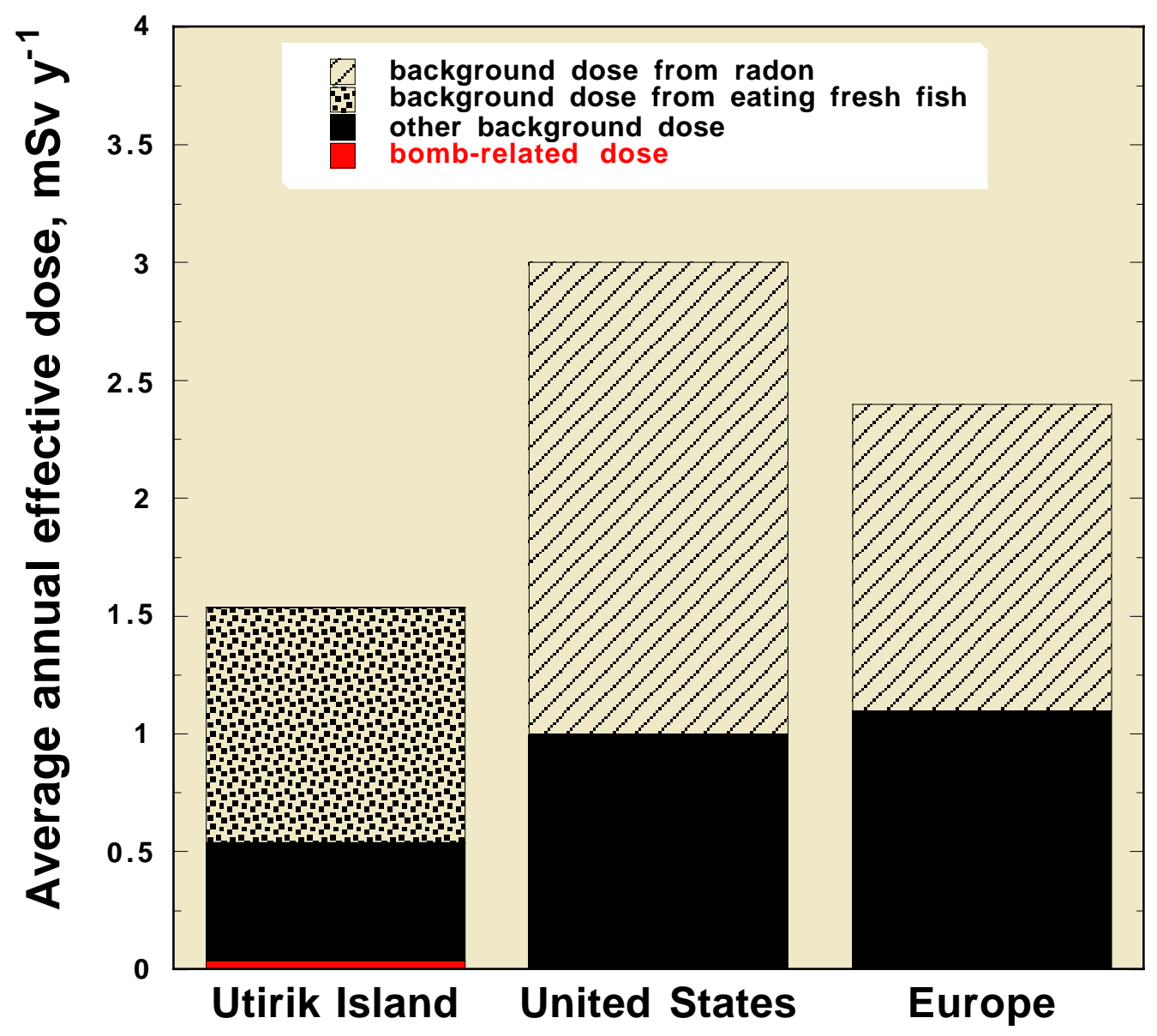

Figure 6. Utirik total annual average effective dose compared to average annual background doses elsewhere. 


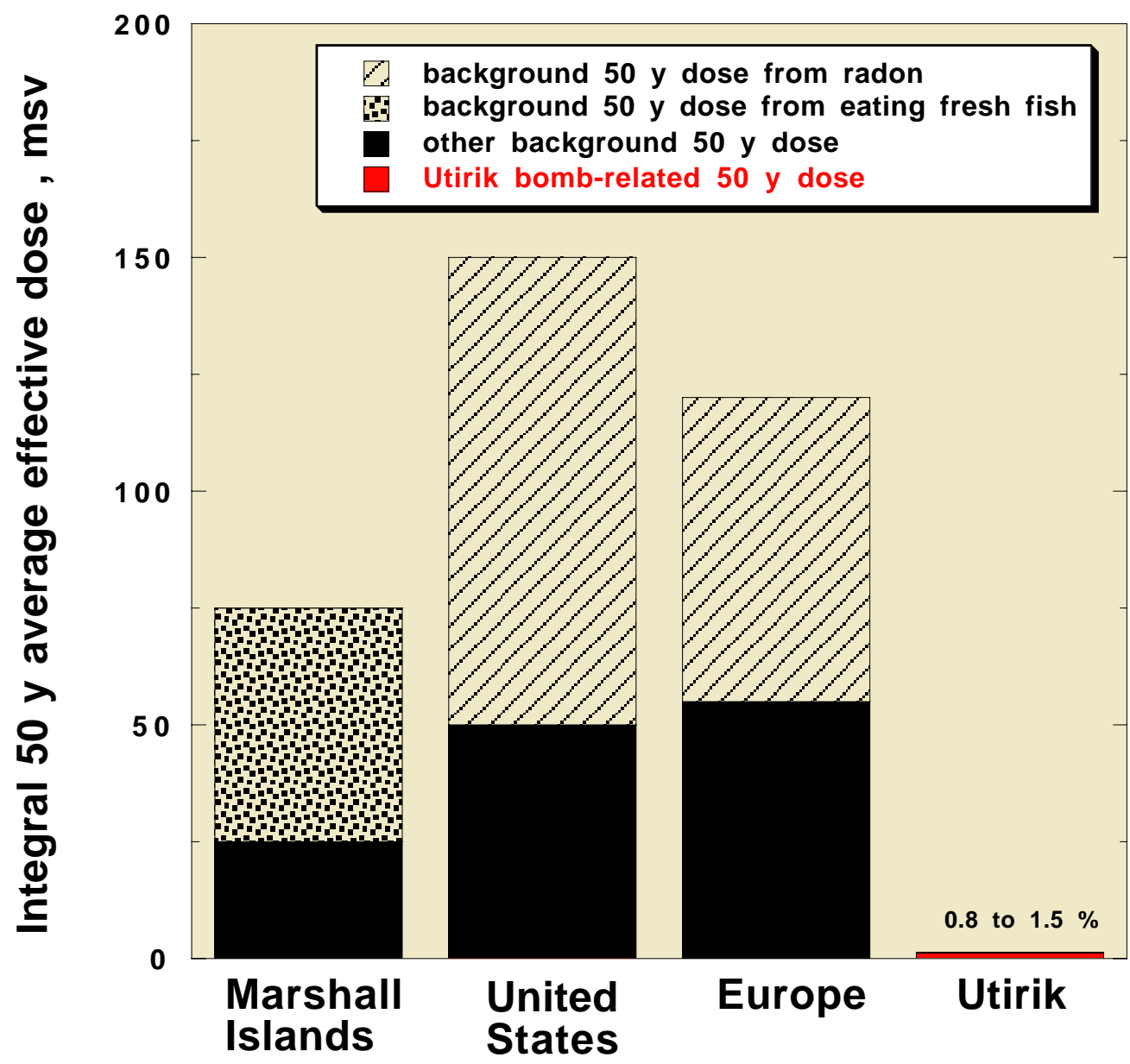

Figure 7. Utirik 50-y integral average effective dose compared to the 50-y integral average background doses. 

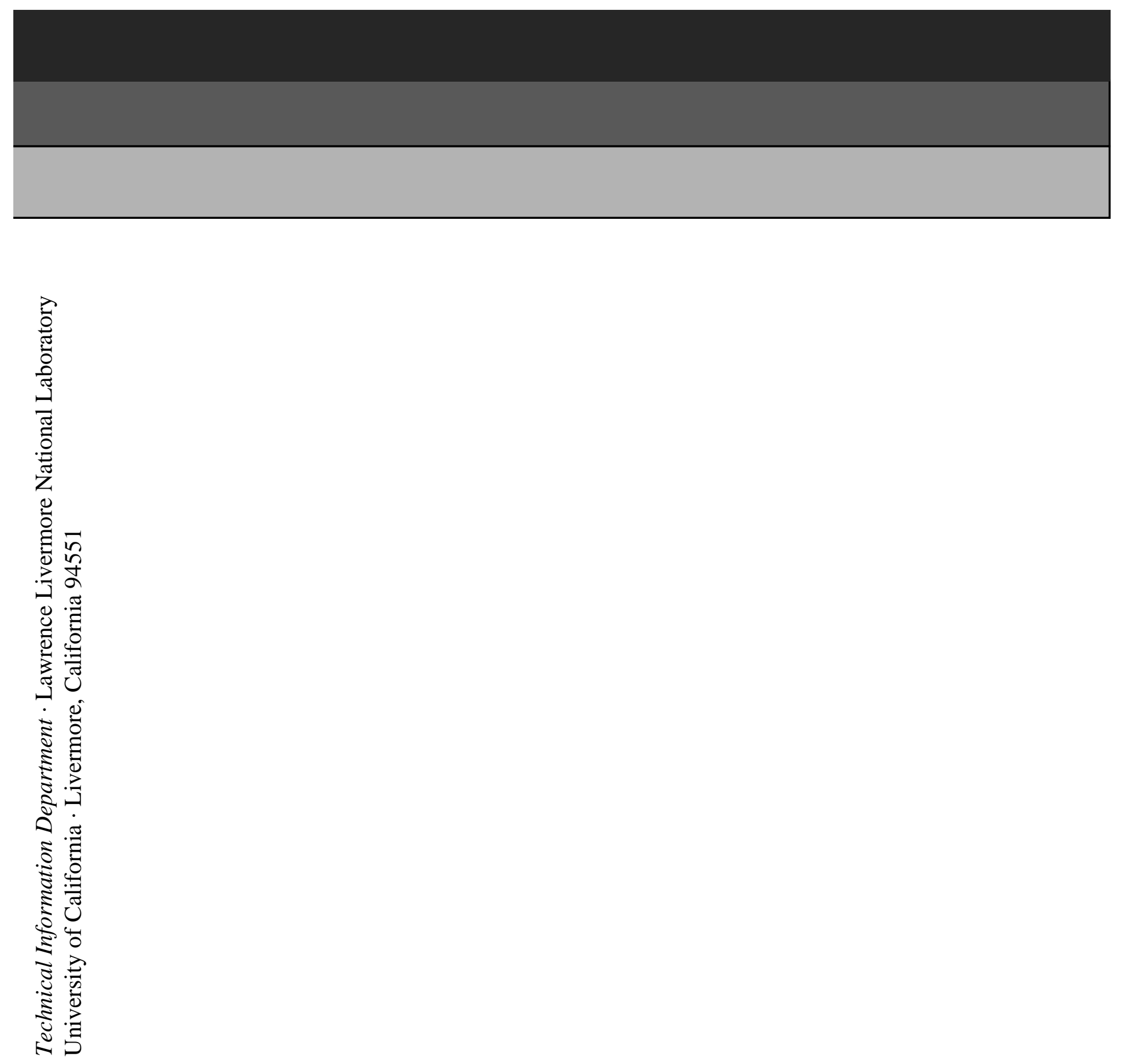